\title{
Sharing of Children Online Information by Parents: The Legal and Parental Control in Malaysia
}

\author{
Mazlina Mohamad Mangsor, Mazlifah Mansoor, Noraiza Abdul Rahman \& \\ Ismah Ismail
}

To Link this Article: http://dx.doi.org/10.6007/IJARBSS/v11-i5/9922

DOI:10.6007/IJARBSS/v11-i5/9922

Received: 15 March 2021, Revised: 20 April 2021, Accepted: 04 March 2021

Published Online: 17 May 2021

In-Text Citation: (Mangsor et al., 2021)

To Cite this Article: Mangsor, M. M., Mansoor, M., Rahman, N. A., \& Ismail, I. (2021). Sharing of Children Online Information by Parents: The Legal and Parental Control in Malaysia. International Journal of Academic Research in Business and Social Sciences, 11(5), 254-266.

\section{Copyright: (c) 2021 The Author(s)}

Published by Human Resource Management Academic Research Society (www.hrmars.com)

This article is published under the Creative Commons Attribution (CC BY 4.0) license. Anyone may reproduce, distribute, translate and create derivative works of this article (for both commercial and non-commercial purposes), subject to full attribution to the original publication and authors. The full terms of this license may be seen at: http://creativecommons.org/licences/by/4.0/legalcode

Vol. 11, No. 5, 2021, Pg. 254 - 266

Full Terms \& Conditions of access and use can be found at http://hrmars.com/index.php/pages/detail/publication-ethics 


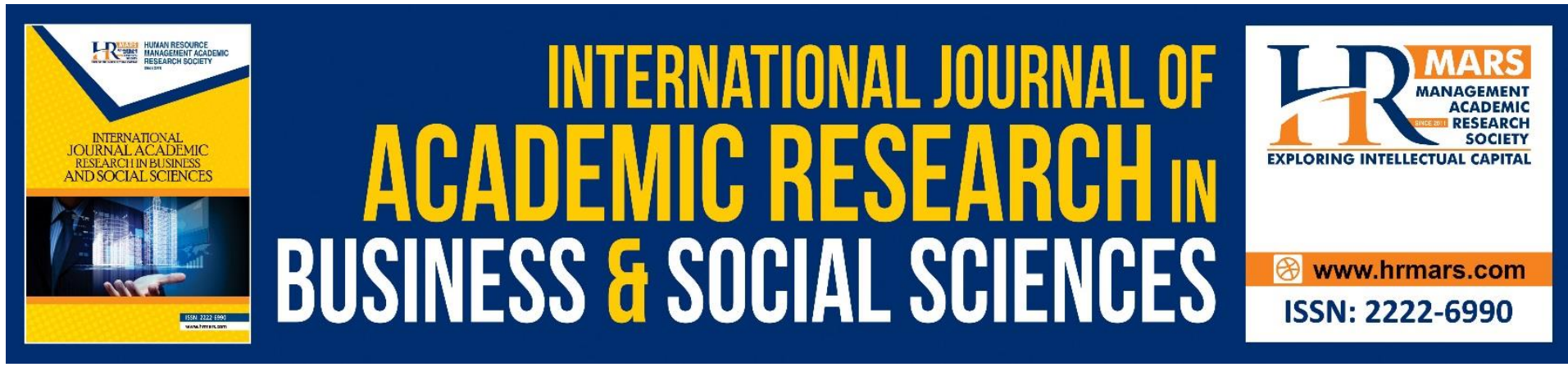

\title{
Sharing of Children Online Information by Parents: The Legal and Parental Control in Malaysia
}

\author{
Mazlina Mohamad Mangsor, Mazlifah Mansoor, Noraiza Abdul \\ Rahman \& Ismah Ismail Senior Lecturers \\ Faculty of Law, Universiti Teknologi MARA, 40450 Shah Alam, Selangor, Malaysia
}

\begin{abstract}
Social media content significantly contributed to the infringement of children's online privacy. The images and information about children shared by parents (sharenting) become easy targets to be used for illicit purposes. The primary question centres around the principle that parents are legally responsible for their children. The UN Convention on the Rights of the Child (CRC) 1989 recognises the main responsibility of parents for the upbringing and development of a child including the best interest of the child. Parents ought to protect the privacy of their children by making informed decisions when sharing the information and images of their children online. The research aims to examine the extent of the legal and parental control over the sharing of children information online by parents. The research employs a qualitative method and applies a content analysis approach. The research concludes that there is insufficient legal and parental control to address the above issues and requires statutory amendments and collective efforts to reconcile the matter.
\end{abstract}

Keywords: Children's Online Privacy, Legal Parental Control, Sharenting.

\section{Introduction}

In the world of Internet of Things (IoT), Big Data and Artificial Intelligence (AI), there is always a general concern about the potential intrusion of online privacy, particularly dealing with children. In Malaysia, Digi Telecommunications, CyberSAFE in Schools: A National Survey Report (2014) reported that children have actual worries about consuming the Internet related to the anonymity of netizens they are communicating with, and invasion of their privacy. Despite $40 \%$ of children in the survey were aware of the online danger, they still adopted low levels of online protection against their privacy and security.

Modern parents share photos and news of their children on Instagram and other online social networks on daily basis, which is also known as "sharenting" (Minkus et al., 2015; Holiday, 2020; Sarkadi, 2020). The shared information by parents on social media enabling the exploitation of information by offenders without the consent of guardians. In 2018, numerous parents were horrified to discover that their children's online pictures had been 
stolen and used on other social media profiles with a different storyline including images of "sweet snaps" of children in disturbing ways (Cambridge, 2018).

Data on children activities online such as gaming is tracked, collected, and exported to third parties by the network providers without notice to the children and the parents. These exploitations are categorised as pursuits of online profiling, online spying, behavioural targeting (Borgesius, 2015) and cyberstalking (Hamin, 2020). The Malaysian Communications and Multimedia Commission (MCMC) has received 652 complaints in 2015 and the number is increasing until 2020, mostly on the spread of indecent photos and videos of complainants across all age groups (Moh, 2016). As a result of the complaints, MCMC raided 11 locations in several states to control abuse of social media and most of the offences were the act of transmitting pornographic content including children images (MCMC, 2019).

The past empirical study strongly supported the notion that parents, and other adults can unintentionally threaten the privacy of children by overcommunicating on online social networks (Minkus et al., 2015). According to Minkus et al. well-meaning parents unintentionally compromise their child's privacy by exposing innocent updates on Facebook and Instagram. The role of parents and parenting practices are crucial in their children's online privacy (Minkus et al., 2015; Hamid, 2020). In light of the above discussions, the objective of the paper is to analyse the Malaysian legal provisions on the obligations of the parents under the laws to control the sharing of their children online communication.

\section{Method}

This paper engages a qualitative and doctrinal research method and applies a content analysis approach where the normative facets of the selected laws are examined. It comprises primary and secondary sources through the library-based research. Whilst the first encompasses of Malaysian legislation, policies and judicial decisions, the latter constitutes a significant proportion of online databases content including IEEE Xplore, LexisNexis and others.

This research adopts the theory of a child's right to an open future by Feinberg (1980). Feinberg highlighted that a child's future option must be kept open until a child is able to decide based on own preference. In this context, a parent is regarded as violating a child's right if sharing of information leads to a closing of an opportunity or an option. Dietrich (2020) argued that if a right to an open future constitutes a legal entitlement, the political and state interventions are welcomed to control parental authorities. Fig.1 shows the nexus of sharing of information by parents and the violation of a child's right leading to the regulating of parental dissenting.

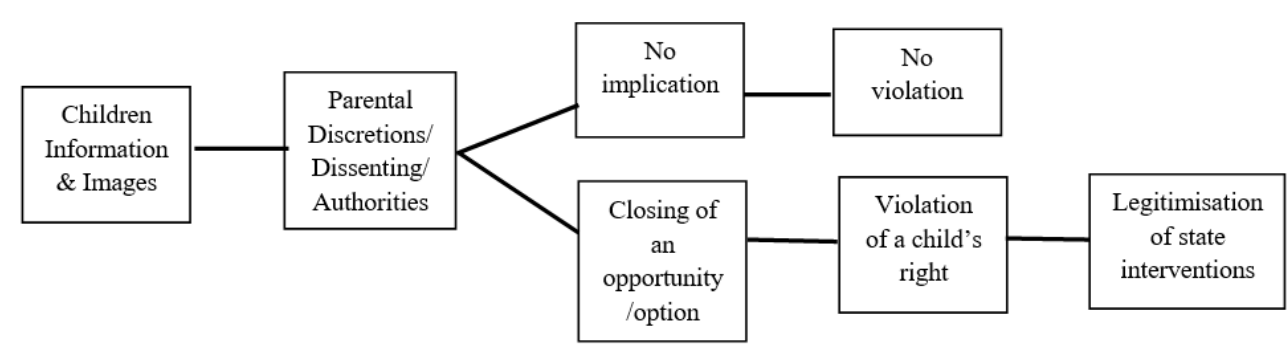

Fig.1: The nexus of sharenting and violation of a child's right 
Within this backdrop, this paper examines the applicability of the Malaysian legal provisions to grant protection of the children's online privacy using the legal framework in Table 1 below. The implications of closing of a child's opportunities or options are argued as an intrusion of a child's privacy. Furthermore, the paper also highlights the possibility of the act of sharing information becoming harmful to the child's digital well-being and physical safety.

TABLE 1: Legal Framework on the Protection of Children Online Information

$\begin{array}{ll}\text { LAWS } & \text { PROTECTION } \\ \text { the CRC } 1989 & \text { TYPE OF LEGAL PROTECTION } \\ \text { to information } 13 \text { and } 16 \text { of } & \begin{array}{l}\text { Children's right } \\ \text { thetection of law against interference }\end{array} \\ & \begin{array}{l}\text { Preedom to seek, receive and impart } \\ \text { information and ideas of all kinds, } \\ \text { regardless of frontiers, either orally, } \\ \text { in writing or in print, in the form of } \\ \text { art, or through any other media of the } \\ \text { child's choice }\end{array}\end{array}$

\begin{tabular}{|c|c|c|c|}
\hline \multicolumn{2}{|c|}{ Principle 3 of the } & Children online & Children's right to request for their \\
\hline United & Nations & privacy & personal data to be corrected or to be \\
\hline $\begin{array}{l}\text { Children's } \\
\text { (UNICEF) }\end{array}$ & Fund & & $\begin{array}{l}\text { removed from the internet and the } \\
\text { right to refrain to parents, media and }\end{array}$ \\
\hline established & the & & the third party from sharing online \\
\hline Children's & Online & & information \\
\hline Privacy & & & \\
\hline Freedom & & & \\
\hline
\end{tabular}

digital literacy skills on sharing of information

Expression: Industry

Toolkit 2018

The legitimation of the state interventions into parental discretions is explored under the existing laws, namely the Sexual Offences Against Children Act 2017, the Communications and Multimedia Act 1998, the Penal Code, the Child Act 2001 and the Personal Data Protection Act 2010. In addition to legal control, Fig. 2 illustrates the discussions on the extent of parental and children control over shared information online.

Fig.2: Legal, Parental \& Children Control

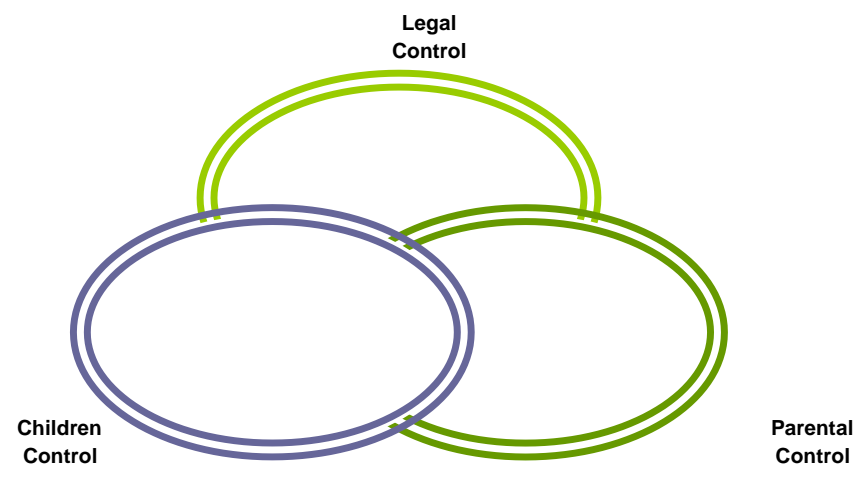




\section{Results and Discussion}

This section discusses the sharing of information by parents and the exploitation of the information. The study establishes that there is an intrusion of privacy by parents when they share information and images of their children online. The ability of the parent(s) to make an informed decision on the type and extent of shared information, their digital skills to prevent exploitation for illicit purposes and the educational measures are also examined in this section.

The focal discussion is on the legal protection against the intrusion of children online privacy and the legal liability of parents for sharing the information online. The paper also analyses the statutory position of the children themselves for their right to privacy, specifically to take control of the shared information online. The research implication is a guideline to assist the relevant authorities to enhance the current initiatives in controlling the sharing of information by parents.

\section{Sharing of Online Information}

Between $66 \%-98 \%$ of parents posted pictures of their children online starting from early pregnancy, the birth of a baby and day one of a child at school (Minkus et al., 2015). In 2018, 24.6 million Malaysian users had actively used five social networking platforms, they are Facebook (97.3\%), Instagram (57.0\%), Youtube (48.3\%), Google+ (31.3\%) and Twitter (23.8\%) (MCMC, 2018). The MCMC reported that $61.8 \%$ of them shared content online with the following purposes

TABLE 3 : Purpose of Sharing Online Content by Malaysian Users (MCMC, 2018)

\begin{tabular}{|c|c|c|c|c|c|}
\hline No & Purpose & $\begin{array}{l}\text { Percentag } \\
e\end{array}$ & No & Purpose & $\begin{array}{l}\text { Percentag } \\
e\end{array}$ \\
\hline 1 & Content is beneficial & $87.2 \%$ & 5 & Generate discussion & $55.8 \%$ \\
\hline 2 & $\begin{array}{l}\text { Raise awareness about an } \\
\text { issue }\end{array}$ & $82.3 \%$ & 6 & $\begin{array}{l}\text { To get likes and } \\
\text { followers }\end{array}$ & $20.7 \%$ \\
\hline 3 & For entertainment or fun & $64.1 \%$ & 7 & $\begin{array}{l}\text { Promote product and } \\
\text { service }\end{array}$ & $20.2 \%$ \\
\hline 4 & $\begin{array}{l}\text { Share interests or } \\
\text { hobbies }\end{array}$ & $57.7 \%$ & 8 & Others & $0.4 \%$ \\
\hline
\end{tabular}

Table 3 above shows that sharing of information online is for well-intended reasons including for a good cause such as raising awareness about an issue. It can also be said that parents sharing information about their children without the intention or knowledge that the information or images of their children become easy targets to be used inappropriately and uploaded on pornographic websites (Hamid et al., 2019). A chat group with hundred members indecently discussing a screenshot about a prepubescent girl dressed in a swimming costume is an alarming fact that parents are unaware that they are contributing photos of their children online for illicit purposes (Moh, 2016).

Photos shared on news and achievements of a daughter or a son using social media are common practices by parents. A birthday girl wearing princess clothes or a boy holding a gold medal are examples of pictures that received many likes within the family members and the parents' cycle of friends. The popularity of the parents may accelerate the process and the photos may go viral. A picture is worth a thousand words. Those with ability and mala fide 
intentions can profile a child by accessing an image. Basic information of a child daily routine including the location of the school and playground can be gathered by them.

TABLE 4 : Online Threat (UNICEF Malaysia, 2014)

$\begin{array}{ll}\text { Category of threat } & \text { Type of Threat } \\ \text { Online offence } & \begin{array}{l}\text { Cyberbullying, harassment, pornography } \\ \text { Online profiling }\end{array} \\ \begin{array}{l}\text { Sexual grooming, theft, kidnapping } \\ \text { Collecting and selling personal information for } \\ \text { commercial purposes } \\ \text { Selling of date to spammers, malware distributors }\end{array} \\ \text { Online social disclosure } & \begin{array}{l}\text { Overexposure to family, friends, and society } \\ \text { Digital footprints }\end{array}\end{array}$

The shared children information raises concern on the children safety and the children may face collateral risk because of the online exposure. Table 4 above summarises the type of threat that affect the lives of the children in many aspects, sectors and dimensions.

\section{The Malaysian Constitutional and Statutory Position of a Child Right to Privacy}

Article 5(1) of the Federal Constitution states that "no person shall be deprived of his life or personal liberty save in accordance with law". The phrase "life or personal liberty" had been argued to include a right to privacy in numerous cases. The case of Sivarasa Rasiah made a breakthrough to extend the right to personal liberty to include the right to privacy to an adult (2010). In the same year also marked the first case to acknowledge the intrusion of privacy as an actionable tort under the case of Lee Ewe Poh involving a female adult patient complaining about a medical procedure of a surgeon taking and keeping photographs of the intimate part without her knowledge (2010). 
TABLE 5 : Legal Control

\begin{tabular}{|c|c|c|c|}
\hline Laws & Offence & $\begin{array}{l}\text { Prohibition on } \\
\text { sharing of } \\
\text { personal } \\
\text { information on } \\
\text { social media by } \\
\text { third party }\end{array}$ & $\begin{array}{l}\text { Prohibition on } \\
\text { sharing of } \\
\text { personal } \\
\text { information } \\
\text { on social } \\
\text { media by } \\
\text { parents }\end{array}$ \\
\hline $\begin{array}{l}\text { The } \\
\text { Communications } \\
\text { and Multimedia } \\
\text { Act } 1998\end{array}$ & $\begin{array}{l}\text { Manipulating the images of any } \\
\text { person if they are indecent, } \\
\text { obscene, false, menacing, or } \\
\text { offensive }\end{array}$ & No & No \\
\hline The Child Act 2001 & $\begin{array}{l}\text { Ill-treatment, neglect, } \\
\text { abandonment, or exposure of } \\
\text { children or leaving a child without } \\
\text { reasonable supervision } \\
\text { Restrictions on media reporting and } \\
\text { publication of children in court's } \\
\text { proceeding }\end{array}$ & No & No \\
\hline $\begin{array}{l}\text { The Sexual } \\
\text { Offences Against } \\
\text { Children Act } 2017\end{array}$ & $\begin{array}{l}\text { Preparing to make, produce or } \\
\text { direct the making or production of } \\
\text { child pornography as offences. } \\
\text { Prohibit the act of exchanging, } \\
\text { publishing, and selling of the child } \\
\text { pornography material(s). }\end{array}$ & No & No \\
\hline Penal Code & $\begin{array}{l}\text { Circulation of obscene materials, } \\
\text { dealing with sale and distribution of } \\
\text { obscene material } \\
\text { The intrusion upon the privacy of a } \\
\text { person by word or gesture including } \\
\text { exhibiting any object. }\end{array}$ & No & No \\
\hline $\begin{array}{l}\text { The Personal Data } \\
\text { Protection Act } \\
2010\end{array}$ & $\begin{array}{l}\text { The exploitation of personal data in } \\
\text { commercial transactions without } \\
\text { the consent of an adult. }\end{array}$ & $\begin{array}{l}\text { Yes, } \\
\text { commercial } \\
\text { transaction }\end{array}$ & No \\
\hline
\end{tabular}

Table 5 provides for a list of laws that controls circulations and manipulations of online content including the Child Act 2001 for abandonment of a child without supervision. However, none of the legislation clearly addresses the prohibition on sharing of personal information on social media by third parties or parents. 
There is a legal control on sharing offensive information online by making it an offence to circulate indecent or offensive information. According to para 2.5 of the Malaysian Communications and Multimedia Content Code, online content for children must not include "references to sexual practices, language or materials that are offensive to the standards of decency prevailing among those likely to be exposed to them" (CMCF, 2004).

However, sharing of non-offensive information is not prohibited under the laws. Since the information is shared on the public domain and freely accessible to all, it is not prohibited by law per se. In other words, it is not an invasion of privacy for collecting or sharing of nonoffensive information in the public domain. In the case of Sherrina Nur Elena, photographs were taken during beauty pageants and were published in the local newspapers years ago were later produced by the defendant on its products and billboard advertisements. The court rejected the argument of invasion of privacy since the photographs are in the public domain. Similarly, in the case of Ultra Dimension, the court rejected the claim of invasion of privacy by parents of kindergarten pupils against reporters that randomly photographed a group of kindergarten children at an open area outside their school and published the photos in local newspapers (2001). The taking of photographs at the public domain is not prohibited under the law. However, the court may consider a cause of action if a photograph of a child was highly offensive and illustrated a child in an embarrassing position.

The law also does not grant the right for children to protect their privacy by requesting for amendment, correction, or removal of their personal information. The laws listed in table 6 do not expressly grant the children the right to give or refuse consent in sharing information in the public domain. The children also do not have the right to refrain to parents, media or third-party form sharing information online as illustrated in table 6.

TABLE 6 : Children's Right to Refrain from Sharing Information

\begin{tabular}{|c|c|c|c|}
\hline Laws & $\begin{array}{l}\text { Request by } \\
\text { the children } \\
\text { for their data } \\
\text { to be } \\
\text { corrected by } \\
\text { the third } \\
\text { party }\end{array}$ & $\begin{array}{l}\text { Request by } \\
\text { children for } \\
\text { removal of } \\
\text { content they } \\
\text { believe is } \\
\text { damaging to their } \\
\text { reputation }\end{array}$ & $\begin{array}{l}\text { Injunction for parents or } \\
\text { guardians, media outlets } \\
\text { and another third party } \\
\text { from sharing information } \\
\text { that could undermine the } \\
\text { children's current or } \\
\text { future reputation }\end{array}$ \\
\hline \begin{tabular}{ll} 
The & \multicolumn{2}{c}{ Communications } \\
and & Multimedia Act \\
1998 &
\end{tabular} & No & No & No \\
\hline The Child Act 2001 & No & No & No \\
\hline $\begin{array}{l}\text { The Sexual Offences } \\
\text { Against Children Act } \\
2017\end{array}$ & No & No & No \\
\hline Penal Code & No & No & No \\
\hline $\begin{array}{l}\text { The Personal Data } \\
\text { Protection Act } 2010\end{array}$ & No & No & No \\
\hline
\end{tabular}


In conclusion, there is a limited legal protection against the intrusion of children online privacy and the legal liability of parents for sharing the information online. The protection is only against indecent and offensive content. There is also no statutory position granting children the right control information online.

\section{Parental Control}

Parents or legal guardians are primarily accountable for the upbringing and development of a child (Hamid et al., 2020), and mainly a concern for the best interest of the child as entrenched under the UN Convention on the Rights of the Child (CRC) 1989. The CRC was adopted by the Malaysian Government in 1995 with some reservations. The move to introduce the Child Act 2001 was part of the initiatives to protect the children's rights. The reservations were gradually lifted and in 2011, Malaysia became a signatory to the Optional Protocol on child prostitution and child pornography under the CRC.

By virtue of section 2 of the Child Act 2001, a child means a person under the age of eighteen years. Children are under the custody and responsibility of the guardian as stated under section 3 of the Guardianship Infants Act 1961. The law specifies the responsibility of guardian on children's support, health and education.

Children between the age of 16 years to 18 years should be given the right under the law to control their online privacy. Even though section 2 of the Age of Majority Act 1971 set eighteen as the age of majority, but children aged 16 falls under the category of a young person under certain laws such as the Children and Young Persons (Employment) Act 1966 and the Penal Code.

Parents or legal guardians are potential contributors to child information and picture made available online. There is yet a national survey on the precautionary action taken by parents before sharing information online. But a general national survey conducted in Malaysia found that internet users have taken precautionary actions before sharing online content including understanding the content $(90.8 \%)$, ensuring content not obscene, menacing, offensive $(85.8 \%)$, valid and accurate $(79.4 \%)$, verified content from a reliable source $(77.0 \%)$ and only $4.4 \%$ done none of the above (MCMC, 2018). It is safe to say that sharing of children's information and images is done by taking measures to ensure with validity, accuracy and content from a reliable source.

It is also important to address whether parents are aware of the control they can set on the children's usage of the internet and shared information online. MCMC highlighted that $62.4 \%$ of Malaysian parents among Internet users were aware of parental control and $37.6 \%$ were not aware. Parents have taken action to ensure child online safety in the following initiatives:

TABLE 7 : Actions by Parents for Child Online Safety (MCMC, 2018)

\begin{tabular}{l|ll} 
No & Action by parents & Per centage \\
\hline 1 & Set rules and limits of internet usage to the child & $75.5 \%$ \\
2 & Stayed nearby child when he/she used the Internet & $75.4 \%$ \\
3 & Discussed with child about online safety & $71.1 \%$ \\
4 & Checked child's social media account/ browser history & $57.5 \%$ \\
5 & Used parental control service in child's device & $12.2 \%$ \\
6 & None & $7.4 \%$
\end{tabular}


Based on this report, out of $62.4 \%$ of parents who were aware of parental control, only $12.2 \%$ were using parental control service in the child's device. The usage is low considering that other measures cannot be performed $24 / 7$ except for checking a child's account or browser history which may be wholly or partially erased by a child. Nonetheless, these measures and reports do not specifically address the potential intrusion of children's online privacy contributed by parents or legal guardians sharing information or images of their children.

Another initiative for parental control is parental consent in data collection of children. In the United States (US) and the United Kingdom (UK), legal measures have been introduced for the protection of children online privacy including the requirement for parental consent in data collection of children under the age of 13 years old in the US and the age of 16 years old in the UK (Nyst et al., 2018). However, this initiative does not address the concern that children's information and photos made available online by the legal guardians themselves. Parents' lack of awareness and ignorance of technological measure is assumed to contribute to the issue at hand.

\section{Digital Skills}

Parental control on the sharing of information online must be complemented with the digital skills to determine the type and extent of information sharing online. Zakaria et.al suggested a rule-based privacy tool for the parents or legal guardians to decide on online content sharing (2011). Zakaria et.al categorised the level of privacy into the following settings:

TABLE 8 : Level of Privacy (Zakaria et. Al, 2011)

\begin{tabular}{l|ll} 
Level of Privacy & \multicolumn{1}{l}{ Type of Content } & Antecedent \\
\hline \multirow{4}{*}{ High } & $\begin{array}{l}\text { Posts } \\
\text { Photos } \\
\text { Date of Birth } \\
\text { Home Address } \\
\text { Phone Number }\end{array}$ & Friends only \\
Low & $\begin{array}{l}\text { Email Address } \\
\text { Religion }\end{array}$ & Friends of Friend \\
School & Ectivities/ Interest \\
Profile Searchability & Everyone
\end{tabular}

This tool proposed that a low privacy level allows everyone to access information related to a child's school of a child, activities or interest of a child and profile search ability of a child social media account. Disclosing the name of the school of a child is questionably safe for everyone to access. Sharing activities or interests of a child may also be doubtfully risk-free, particularly if the information of activities includes a specific location such as a music studio or a sports training centre.

Also, parents should be informed that social media networks offer choices to a user to limit the privacy setting of an account and any postings with security settings on the sites. The relatives and friends who are permitted to access the images can still distribute them with other users. Parents have additional technological measures by coding and encrypting the images to restrict downloading and possessing of the picture (Moh, 2016). Modern parents 
may find the steps easy to execute but the older generations may have technical difficulties to apply the security measure.

\section{Educational Measures}

In Malaysia, the regulatory authority, the MCMC has jointly organised awareness programs for the parents continuously. The non-governmental organisations and the telecommunications companies are also assisting the MCMC in the campaign for the parents to reach out to the children (Chow, 2018).

One of the initiatives was a town hall meeting and UNICEF also launched the 'State of the World's Children (SOWC) 2017: Children in a Digital World' report which educates parents to understand safe Internet practices and how to protect their children online (Chow, 2018). In the same event, a digital safety advocate highlighted that parents must be empowered to learn online dangers and must be able to handle a situation if the child became a victim of online abuse (Chow, 2018). Cyber awareness also demanded that parents need to control themselves from cyber addiction using handphones.

Furthermore, the MCMC plays the role of providing technical assistance to the police force, if required. The police have formed a special child cyber sexual investigation unit to trace those involved. The government agency also has taken initiatives to carry out the national council for children and welfare team for children at the district level. A child registry has been created to cover a list of offenders linked to crimes involving children.

\section{Conclusion}

The technologies of IR4.0 need to be utilised wisely by the parents or guardians to shape the online future of their children. Parents may unintentionally jeopardise their children's privacy and safety. Ignorant of the third-party abilities that are supported with the advancement of technical tools and applications is not an excuse to ensure the safety, security, integrity, and privacy of the children online and offline

The current laws only address offensive information shared by a third party or media. There is a lacuna in law to control and limit the act of sharing of children's information by parents. The existing parental control also has not been effectively exercised by parents. First, there is ignorance of making an informed decision on what to share online about their children. Second, parents have a lack of digital skills to set a limit to the privacy setting of an account and any postings with security settings on the sites. Parents are not equipped with additional technological measures by coding and encrypting the images to restrict downloading and possessing of the picture. Third, parents lack digital safety knowledge and expertise in handling a situation if the child became a victim of online abuse.

The existing measures do not include children's own right to control the information shared online. The parents are given the right to create a social media account of their children without consent from their children. Similarly, children are also not authorised to sign a consent letter for the sharing of information. Majority of the social media network provides for age restrictions to create an account. This restraint to some extent grants safety technological measures preventing children below a certain age to form an account. However, if an account is established by a father or a mother, the child has no say on the matter. Certain laws recognised children of 16 years to have the right as an employee under the Children and Young Persons (Employment) Act 1966 and to be charged for criminal offence under the Penal 
Code. Accordingly, 16 years as the age of consent to be legally competent to consent or refuse consent online should be set under the law as the age of being capable to control online privacy in Malaysia.

The paper concludes that the features of Feinberg's theory are essential in nurturing a child's right to online privacy. Sharing of information by parents requires certain limitations if the action resulted in closing of an opportunity or an option. There is a necessity to address this implication if it is harmful to the child. Restraints in a form of legal and parental controls is proposed with the support of other initiatives including technological and educational mechanisms.

\section{Acknowledgements}

The authors gratefully acknowledge the help of Pejabat Research Nexus UiTM (RENEU) for organising a workshop on writing skill on 14-15 September 2020, at Institute Kepimpinan dan Pembangunan (ILD), Bandar Enstek, Negeri Sembilan, Malaysia. The authors are also thankful to the Faculty of Law, Universiti Teknologi MARA, Shah Alam, Malaysia. for supporting the research activities financially and professionally.

\section{References}

Borgesius, F. Z. (2015). Informed Consent: We Can Do Better to Defend Privacy. IEEE Security \& Privacy, 13 (2), 103-107, March-April.

Cambridge, E. (2018). I Felt Sick' Mum's Social Media Pictures of Kids: Milestones Stolen and Used by Sick Trolls - Here's How To Keep Your Pictures Safe. The Sun. https://www.thesun.co.uk/news/7189729/mum-social-media-pictures-childrenstolen/

Chow, S. (2018). Your children will tell you about abuse. The Star. https://www.thestar.com.my/news/nation/2018/02/11/your-children-will-tell-youabout-abuse-malaysian-youths-trust-parents-to-help-tackle-online-sexual.

Communications \& Multimedia Content Forum of Malaysia. (2004). Communications \& Multimedia Content Code. Malaysian Communications \& Multimedia Commission.

CyberSAFE. (2014). Digi Telecommunications, CyberSAFE in Schools: A National Survey Report 2014. https://digi. cybersafe.my/files/article/CyberSAFE_Survey_ Report_2014.pdf

Dietrich, F. (2020). Liberalism, Neutrality, and the Child's Right to an Open Future. Journal of Social Philosophy, 51 (1):104-128.

Feinberg, J. (1980). "The Child's Right to an Open Future". In Aiken, W. and LaFollette, H. (1980). Whose Child?: Children's Right, Parental Authority, State Power. Totowa NJ: Littlefield, Adam \& Co, 124-153.

Hamid, S. N. F. A., Ahmad, Y., \& Tahir, N. S. (2020). Parenting practices and parenting styles in upholding child protection and privacy to address pedophilia in Malaysia. Journal of Critical Reviews, 7 (8), 1708-1712.

Hamid, S. N. F. A., Ahmad, Y., \& Tahir, N. S. (2019). Scrutinising the socio-demographic pattern of parenting practices and parenting styles in upholding child's protection and privacy to address pedophilia issue. Research in World Economy, 10, 2 Special Issue,108116.

Hamin, Z., \& Wan Rosli, W. R. (2020). Whither the Protection for Cyberstalking Victims? 
Some evidence from Malaysia. Environment-Behaviour Proceedings Journal, 5(SI1), 5358. https://doi.org/10.21834/ebpj.v5iSI1.2297

Holiday, S., Norman, M. S., \& Densley, R.L. (2020). Sharenting and the extended self: selfrepresentation in parents' Instagram presentations of their children. Popular Communication.

Lee Ewe Poh v Dr Lim Teik Man \& Anor. (2010). LNS,1, 1162.

Malaysian Communications \& Multimedia Commission. (2019). Bernama, social media Abuse: MCMC raids 11 locations in several states. Media \& Events. https://www.skmm.gov.my/media/press-clippings/social-media-abuse-mcmc-raids11-locations-in-save.

Malaysian Communications \& Multimedia Commission. (2018). Internet Users Survey 2018. https://www.mcmc.gov.my/skmmgovmy/media/General/pdf/Internet-Users-Survey2018.pdf.

Moh, J. (2016). Hide Your Kids from Social Networks. The New Straits Time. https://www.nst.com.my/news/2016/06/151356/hide-your-kids-social-networks.

Minkus, T., Liu, K., \& Keith W. Ross, K.W. (2015). Children Seen But Not Heard: When Parents Compromise Children's Online Privacy. International World Wide Web Conference Committee. http://cse.poly.edu/ tehila/pubs/WWW2015children.pdf.

Sarkadi, A., Dahlberg, A., Fängström, K., \& Warner, G. (2020). Children want parents to ask or permission before 'sharenting'. Journal of Paediatrics and Child Health, 56 (6), 981-983.

Nyst, C., Gorostiaga, A., and Geary, P. (2018). Children's Online Privacy and Freedom of Expression: Industry Toolkit. United Nations Children's Fund (UNICEF).

UNICEF Malaysia. (2014). Exploring the Digital Landscape in Malaysia: Access and use of digital technologies by children and adolescent. UNICEF Malaysia.

Zakaria, N., Yew, L. K., Alias, N. M. A., \& Husain, W. (2011). Protecting privacy of children in social networking sites with rule-based privacy tool. Proceedings of the 8th International Conference on High-capacity Optical Networks and Emerging Technologies (pp253-257). IEEE Xplore. 